\title{
EUROPEAN EMPLOYMENT GUIDELINES: FROM THEORY TO EU TREATIES
}

\author{
Ana-Maria UDREA (COATU), PhD student \\ Faculty of European Studies \\ Babes-Bolyai University Cluj-Napoca, Romania \\ anam.udrea@gmail.com
}

\begin{abstract}
:
Nowadays, in connection with work force and employment policies, European Union finds itself in a continuous process of evolution and transformation. As a result of the constraints offered by the historical changes and challenges, European Union has to deal with the effects of: the free movement of the work force, the economic and financial crisis, the ageing of the population, and the migration crisis. All these challenges have determined an increasing attention and focus on the social dimension and employment policies at EU and national state level through guidelines, country recommendations, and specific strategies. At the same time, from the perspective of EU treaties these challenges have not been foreseen - it have not been possible as well - but, on the other hand, there are a series of principles and guidelines which, theoretically, should have a positive impact on the European labour markets. In this regard, this article intends to offer more a preview on the evolution of the employment policies within European Union and present the concrete issues and problems EU should address.
\end{abstract}

Keywords: employment, Europe 2020, EU Treaties, work force, labour markets

\section{Introduction}

Nowadays, in connection with work force and employment policies, European Union finds itself in a continuous process of evolution and transformation. As a result of the constraints offered by the historical changes and challenges, European Union has to deal with the effects of: 
- The liberalization of labour movement and the increase of its mobility, which creates legal problems, social conflicts derived from the general perception of the resident population that immigrants "steal" their jobs, increased conflicts and the migratory wave of refugees from the Middle East;

- The economic and financial crisis that generates new social problems caused by budget constraints, such as unemployment whose diminution would mean increasing economic investment in creating new jobs, as well as increased financial cost in granting unemployment benefits;

- The aging of the population and in particular, the labour force, as well as the high unemployment among the young population.

All these challenges have given rise to an increased importance of the social dimension and employment policies both within the European Union as a whole at the level of legislative regulations, country and strategy recommendations, and at the level of Member States at legislative and national policy level employment. In order to ensure employment, social and economic progress, inclusion and social protection, the European Union acts through three mechanisms/ instruments (Employment and social affairs, sine anno):

- Legislative instruments - such as treaties, directives, recommendations, communications;

- Policy tools - such as the European Semester, multi-level governance, open method of coordination;

- Financial instruments - such as grants, the European Program for Social Change and Social Innovation.

Thus, throughout this article, we will refer to all these to better outline and understand the complexity of employment policies within the European Union, basing our research on a series of primary and secondary documents using qualitative research techniques (analysis, synthesis). The aim of this approach is to investigate the evolution of 
Issue no. 22/2017

the social policies of the European Union as part of the desideratum of shaping a European social model from the employment theories elaborated by the economists to the guidelines reflected in the EU Treaties.

\section{Human capital and work force market}

Nowadays, in the new conditions of the information society, the human resource represents the essential factor for the development of an organization and of a society in general. The difficulties faced by the entire Romanian transition society are reflected in a series of imbalances in the labour market. Given the inexistence of in-depth research in this field, one can speak of an informational void that makes it difficult to design coherent human resource development strategies at both national and regional level.

It is in the nature of man to want to get more, so also in terms of economic growth, over the centuries there has been a preoccupation for this study, and a series of theories have developed. Analysing the patterns of economic growth and socio-economic development, it is noted that they are built on the approach of the economy as a closed economy as a closed society. The main factors of economic growth and socio-economic development are: increase in labour force, increase of stock capital and technical progress.

The increase in labour supply allows the company to produce more goods and services, leading to higher per capita output and in terms of revenue, that allows the acquisition of these goods, then one can say that labour supply has increased welfare social. Labour growth depends on the following factors: demographic growth, international migration, occupancy rate.

- The demographic increase refers to the fact that the natality rate is higher than the mortality rate. Demographic growth is the main driver of the labour force, but also of the consumers of the effects (outcomes) of the economy; 
Issue no. 22/2017

- International migration refers to the degree of international labour mobility. Net immigration tends to increase the labour force available in a country, while net emigration has the opposite effect;

- Occupancy rate is the percentage of the active population relative to the total population. The employment rate influences economic growth by the fact that if it is high it means that the unemployment rate is low and that the burden of supporting the pensioners is lower.

Labour productivity growth can also be analysed from the perspective of the main factor that determines the increase of the capital stock - by the saving and then the investment phenomenon - as well as the determinant factor of the technological progress. That is why the formulation of "human capital" may be more appropriate. This is the artisan of economic growth and social development, but also its beneficiary (Becker, 1975).

Labour force is only useful to the extent that it has a purpose beyond the productive aspect. In the end, it must be able to innovate to determine technological progress. In this respect, it contributes to the public capital, through the education offered by the state or by creating its legal structures of manifestation.

We believe that today economic growth and social development must be based mainly on the following qualitative factors:

- Directing equity to net investment in expanding industries, for which there are market outlets;

- Increasing the quality of human resources, seen as a work force, i.e. a force producing goods and services;

- Improving soil quality, environmental protection can also be included here;

- Maintaining a high level of demand, consistent with maximizing the use of production factors, boosting the specialization and expansion trend, with beneficial effects on costs and the allocation of research funding. 
Given that growth can be defined as an increase in the welfare of the population, we can say that the very natural character of natural resources, which determines the limited nature of economic goods, can limit "this well-being". So, demography, economic growth and the impact of man on the environment are closely linked.

It is necessary to take into account the evolution of the population and the impact on the environment in the process of establishing economic policies.

Occupation is the term used in Romanian to define the quality of a person to be engaged in productive, paid and legal work. English uses the word "employment", and in French we find the term "emploi" (Glossary of Statistical Terms, OECD, sine anno) ("job" - a place to work on). According to the International Labour Office, an accepted definition at the level of the European Union on the employed population is that:

"all persons aged 15 and over who have carried out an economic activity producing goods or services for at least one hour during the reference period Weekly) in order to obtain income in the form of wages, benefits in kind or other benefits" (Report of Romanian National Institute of Statistics on Work force in Romania. Employment and Unemployment, 2009).

In 1938, the Committee of Statistics Experts of the League of Nations recommended the classification of the occupied population into four categories: employers, self-employed, domestic workers and paid employees. This was the first step in defining employment status. The same four categories were also used at the Sixth International Conference on Workers' Statistics in 1947 and at the Eighth Conference in 1954 (According to ILO, Status in employment - History, sine anno). In 1950, the United Nations Population Commission adopted a standard definition of the four categories. In 1958, the fifth category was added, namely "members of cooperative producers". Currently, since 1993 there are six categories: employees, employers, self-employed, cooperative producers, domestic workers, workers who cannot be classified (Resolution 
concerning the International Classification of Status in Employment (ICSE), adopted by the Fifteenth International Conference of Labour Statisticians, 1993).

The International Labour Organization (ILO) has organized eight main conferences that debated fundamental principles and rights at work, such as: free association and the right to bargain collectively, the elimination of all forms of forced labour, the elimination of exploitation of children through work, eliminating discrimination at work. The eight conferences were held as follows: 1. 1930 - Forced labour; 2. 1948 - Free association and protection of this right; 3. 1949 - The right to organize collective bargaining; 4. 1951 Right to equal pay; 5. 1957 - Abolition of Forced Labour; 6. 1958 - Discrimination (employment and occupation - profession / trade); 7. 1973 - Minimum retirement age; 8. 1999 - Serious forms of exploitation of children through work (Conventions and Recommendations, ILO, sine anno).

\section{Economic theories on work force employment}

The issue of employment and labour has raised the interest of many economists, beginning with classical economists: Adam Smith, David Ricardo, John Stuart Mill, Karl Heinrich Marx, John Maynard Keynes, and John Kenneth Galbraith or Friederich August von Hayek. Occupation is defined as the balance of supply and demand, and on the other hand, the employment is defined as a population aged between certain age limits and carrying out an economic activity generating profits.

Adam Smith (1723-1790) is the first economist to discuss the division of labour before the industrial revolution as an important factor in enhancing the "wealth of nations" (Popescu, 2004, p. 143). The division of labour is directly linked to productivity, so the specialization provides a higher degree of productivity. If Aristotle brings to mind the social-animal (zoon politicon), Adam Smith takes this vision forward and develops a new "homo oeconomicus" thinking system; the economy being a social science because it needs society to produce itself and because it influences almost all the functioning 
Issue no. 22/2017

mechanisms of a society. Beyond the aspiration for full employment, Adam Smith points out that this is only more likely if the accumulated capital increases, because this increase will lead to the need to employ more "labour forces" (Popescu, 2004, p. 147).

David Ricardo (1772-1823) calls into question supply and demand, highlighting that, in general, labour supply is higher than demand in economy, "because the population tends to grow faster than capital accumulation and wealth increase" (Popescu, 2004, p. 219).

John Stuart Mill (1806-1873) explains the existence of the three primary factors of production: labor, nature and capital. One of its principles is that

"The best state for human nature is that nobody is rich, nobody aspires to become richer and is not afraid to regress the cause of the efforts made by others to advance" ( Denis, 1983, p. 467), which is in accordance with the idea of a certain social harmony under conditions of economic liberalism ${ }^{20}$.

Moving on to Marx (1818-1883), his conception of work led to the emergence of socialism, as he stated that it was necessary "to take over the means of production by the workers and place the production to be social control" (Popescu, 2004, p. 361), thus proposing an economic system Leading to social equality ${ }^{21}$.

Keynes's economic and social conception (1883-1946) calls into question economic liberalism, which he regards as "laissez-faire", creating the concept of "driven capitalism" to emphasize that social and individual interests do not always coincide; the state has the

\footnotetext{
${ }^{20}$ In the initial phase of research into this issue of youth employment, we also wondering whether it is of little use for a state or the European Union to have as many active young people as possible, than to become a burden on the state and their families, Becoming social assistants. In this respect, Henry Denis's commentary on the economic conception of J.S. Mill, urged us to explore the issue more closely, although we do not think that anybody could say that high unemployment is preferable or that youth employment policies should not be created. But we intend to explore this conception by identifying solutions that would lead to a certain state of balance and social harmony.

${ }^{21}$ A utopian conception that does not solve the problems faced by mankind in any of its times.
} 
duty to solve certain social problems, because "if not decided and fulfilled by the state, they will not be made by anybody" (Moggridge, 1995, p. 456).

Keynes is one of the economists whose fundamental concern was to identify solutions to reduce unemployment, ie to establish a correlation between the economic development of a state and the level of employment available (Keynes, 1970, p. 63-65). In his view, full occupation is a special case that arises from the balance between the propensity for consumption and the impetus for financial investment. It also draws attention to the fact that

"the main shortcomings of the economy of the society in which we live are its inability to ensure the full use of the labor force and the arbitrary and unfair distribution of wealth and income" (Keynes, 1975, p. 375).

The economic concept of Nobel Laureate John Kenneth Galbraith (1908-2006) is that the perfect (not ideal) society should give everyone the right to have a satisfying existence from the point of view of each individual (It does not refer to equality between people, because it makes the difference between the fact that for an individual a satisfying existence is generated by his gains, while for an artist, freedom is the one that gives him satisfaction). Just like Keynes, Galbraith is an apostle of state intervention in the economy to lead to the real development of the economy (Hayek, 1998, pp. 109-112). Friederich August von Hayek (1899-1992) opposes the intervention of the state in the economy and society, considering that the state must ensure that all citizens respect the "common abstract rules" deriving from "natural laws". This way, the greater freedom

"can be ensured by uniformly rejecting the freedom of all by uniformly rejecting the liberation of all by abstract rules that prevent coercive, arrhythmic or discriminatory acts on the part of one or men, which prevent everyone from invading the free sphere of another. (...) If obedience to common concrete purposes is synonymous with 
slavery, obedience to common abstract aims (however burdensome it may nevertheless appear) offers the possibility of the most extraordinary freedom and diversity" (Hayek, 1998, p. 121).

In the employment plan, this doctrine can be transposed by the fact that beyond government regulations, each individual is responsible for finding a job, according to his/ her own capabilities and aspirations.

In the design and implementation of policies related to employment as high as possible, guaranteeing adequate social protection, combating social exclusion and ensuring equal opportunities for women and men, the European Union uses treaties, common policies and institutions at national and European level (Luţaş, 1999).

Europe after the Second World War was a Europe that no longer wanted to go through these atrocities, and the new vision was to ensure peace among European defeated and defeated peoples, based on the notion of non-aggression and cooperation economic. So, six founding countries (France, Germany, Italy, Belgium, Holland, Luxembourg) have initiated what the European Union has become today through two constituent treaties (Paris, 1951, Rome, 1957) six decades ago. The construction initiated by Monnet, Schuman, Adenauer and De Gasperi aimed at a structured organization of Western Europe, based on common interests and grounded in treaties between the respective states in order to guarantee the rule of law and equality between states. In more than half a century of existence and characterized by a unique evolution in the world, the European Union has come to include 28 Member States and five other States have been granted candidate status, thus, Great Britain has voted to exit the EU. The proportion of the process of European integration and construction is not limited to the number of Member States, but is defined by the complexity of the institutional and functional framework of the Community construction. 
Issue no. $22 / 2017$

\section{Brief history of European treaties}

Every legislative, legislative act is carried out by the EU institutions based on the Treaties, which the Member States then apply, "any measure taken by the EU derives from treaties that have been voluntarily and democratically approved by all member countries. (...) if a specific policy area does not form part of a treaty, the Commission cannot propose a legislative act in that area" (EU treaties, sine anno).

Treaties can be classified as follows (EU treaties, sine anno):

- Founding treaties: the Treaty establishing the European Coal and Steel Community (Treaty of Paris, 1951), the Treaty establishing the European Atomic Energy Community, and the Treaty establishing the European Economic Community (Treaty of Rome, 1957) Treaty on European Union (Maastricht Treaty, 1992);

- Treaties amending basic Treaties (Luţaş, 1999): Single European Act (1986), Amsterdam Treaty (1997), Treaty of Nice (2001), Treaty of Lisbon (2007);

- Accession treaties: the Accession Treaty of Denmark, Ireland and Great Britain (1972), the Treaty of Accession of Greece (1979), the Treaty of Accession of Spain and Portugal (1985), the Accession Treaty of Austria, Finland and Sweden 1994), the Treaty of Accession of the Czech Republic, Estonia, Cyprus, Latvia, Lithuania, Hungary, Malta, Poland, Slovenia and Slovakia (2003), the Treaty of Accession of the Republic of Bulgaria and Romania (2005) (2012);

- Treaties in force: the Charter of Fundamental Rights of the European Union (2012), the Treaty establishing the European Atomic Energy Community (consolidated version 2012), the Treaty on the Functioning of the European Union (consolidated version 2012), the Treaty on European Union.

It should be noted that the different forms of integration defined by the Treaties have become operational not at the time of their signature but only when the Treaties have entered into force. 


\section{Employment in the EU treaties}

If free movement of labor is enshrined in the Treaty of Rome, specific employment policies are the responsibility of the Member States, as long as they respect certain principles and guidelines drawn up by strategies, directives and communications at European level. One of the objectives pursued by these regulations is to coordinate employment policies to "promote a trained workforce with increased and adaptable skills and flexible labor markets for trade" (Ivanov, 2008).

The Treaty establishing the European Economic Community (Rome, 1957) proposes a series of measures aimed at promoting cooperation between Member States (chaos at that time) in order to increase the quality of life and strengthen relations between Member States. Two of these provisions are the subject of our interest in employment in the European Union, namely the liberalization of the movement of persons and the creation of the European Social Fund. The Single European Act aims to revise some of these measures in order to make them easier and clearer to implement, so some of the articles of the EEC Treaty have undergone amendments and additions. The first part of the treaty concerns the liberalization of the goods and services market, people and capital, and the second part proposes a series of procedural reforms concerning the European Council's decision-making process, ie the Council of Ministers (Moravcsik, 1991). The Single Act introduces two new social policy provisions to the EEC Treaty: "Improving the working environment to protect the health and safety of workers" (Article 118a of the EEC Treaty), namely the Commission's role in developing the social dialogue at the level of (Article $118 \mathrm{~b}$ of the EEC Treaty). The Single Act aims to develop a Community policy of economic and social cohesion to reduce development disparities between regions and create a strong single market.

The objectives of the Treaty on European Union (Maastricht, 1992) sought to support economic and social progress by stimulating economic and social cohesion and harmonizing working and living conditions, leading to the development of human 
resources and the reduction of unemployment. Thus, the European Union's employment concerns have manifested itself with the Maastricht Treaty, where the necessary framework for shaping a European social policy has emerged, thus anticipating the objectives of the future European Employment Strategy (Vârşan, sine anno).

Some of the provisions of the Treaty of Amsterdam (1997) represent a step forward in the concern about the employment of citizens. Moreover, this treaty comes with a section on employment and the fight against unemployment concentrated in four directions: availability for employment, entrepreneurship, adaptability and equal opportunities (European Parliament, sine anno).

Despite these concerns about employment, the European Union has failed to provide real employment opportunities for all. Thus, this objective remains open and represents a challenge for both the European Union and each Member State. Some of the impediments to the achievement of this objective are the following: economic and financial crises (1970, 1980 - oil crisis, fall of communism and the 1990s, 2008 crisis), lack of integrated social and economic policies at macro level, on the one hand, and the low capacity to cope with the current labour market transformations of micro-barriers, on the other.

\section{Europe 2020 Strategy}

The Europe 2020 strategy, launched in 2010, comes as a follow-up to the Lisbon Strategy and aims to create jobs and growth. The strategy can be summed up to ensure smart, sustainable and inclusive growth. Objectives focus on the following areas: "employment, research and development, climate change and energy, education and the fight against poverty and social exclusion". Employment is one of the five objectives of the Europe 2020 strategy and an awareness of the Lisbon Strategy. Through the actions covered by the Europe 2020 Strategy, increased attention is paid to youth employment policies, especially for young people with medium or sub-media backgrounds. The 
creation of new jobs, more diverse as fields of activity, together with training, qualification and retraining measures, would be two of the most important elements in improving youth unemployment. The job offer for young people, especially for those without adequate training, is quite limited. They can work in areas such as commerce, construction, tailoring, public catering, but even for these areas they are poorly trained and lack financial motivation. Thus, the situation of youth unemployment in Romania is quite congenial due to the lack of real opportunities on the labour market, poor practical training, inconsistent with the market needs and the low level of the Minimum Income on Economy. As a consequence, there is a situation in the labour market in Romania where there is a job offer in areas requiring an average level of practical training, such as: turning, milling, electrician, plumber, but there is no demand for such jobs from young people because poor training and lack of financial motivation.

Nowadays, there is a trend among young people, namely the high preference for home work or jobs where work schedules are flexible. But there is also the reverse of the medal, so the black labour market is abundant of young people working in baby-sitting, elderly care, multi-level marketing systems (sales). Many people without a job prefer to work in such jobs abroad to secure their economic survival. Whether working in the country or working abroad, these young people do not appear in the statistics of the busy population nor as unemployed.

The joint Commission and Council Employment Report (Draft of the common report of the Commission and the Council on Employment, 2016) in the Commission's Communication on the Annual Growth Survey 2016 summarizes a series of observations on progress towards the Europe 2020 objectives. Of these, five observations are relevant to our article:

1. The rate of employment and social status is gradually improving despite the persistence of some cleavages between and within Member States. 
2. Member States have continued their efforts to stimulate youth employment and reduce the proportion of those defined by the NEET. Thus, the youth unemployment rate in the EU follows a downward trend, but not all countries, with some differences remaining considerable.

3. In this respect, it is noted that the rate of young people who are not professionally employed and do not attend any education or training program (NEET) is decreasing.

4. The major challenge for social and employment policies is the reintegration of long-term unemployed into the labour market. It is alarming that long-term unemployment currently accounts for $50 \%$ of the unemployment rate.

5. A widely used and widely used instrument is subsidies to stimulate employment and job creation.

\section{Conclusions}

From the start of the European Community, the balance between the economic dimension and the social dimension has always been in imbalance, mainly because of the refusal by member states to renounce at a what can be perceived as a too large a share of their competences over social policies and economic and fiscal policies. In this context, the role of the treaties is to offer the legal reasoning to create strategies which should and could prepare the European Union for facing the shock from globalizing economies and to manage the relations between member states.

\section{References}

\section{Books and articles}

1. BECKER, GARY, S. (1975), Human Capital: A Theoretical and Empirical Analysis, with Special Reference to Education, Second Edition, Bucharest: NBER;

2. DENIS, H. (1983), Hystoire de la pensée économique, 7èmé edition, Paris: PUF; 
3. HAYEK, F. A. VON (1998), Infatuarea fatală. Erorile socialismului, Bucharest: Antet;

4. IVANOV, E. (2008), "Conceptul de muncă în doctrina democraţiei creştine", in Gherghina, S.; Jiglău, G.; Pecican, O.; Pop, F. (coord.), Tratatul de la Lisabona. UE către reformă instituţională şi consens, Cluj-Napoca: Dacia;

5. KEYNES, J., M. (1970), Teoria generală a folosirii mâinii de lucru, a dobânzii şi a banilor, Bucharest: Ştiinţifică;

6. LUŢAŞ, M. (1999), Integrare economică europeană, Bucharest: Economică;

7. MOGGRIDGE, D. E. (1995), Maynard Keynes. An Economist`s Biography, London: Routledge;

8. MORAVCSIK, A. (1991), Negotiating the Single European Act: national interests and conventional statecraft in the European Community, available at: (https://www.princeton.edu/ amoravcs/library/sea.pdf), last accessed on: 12.04.2016;

9. POPESCU, G. (2004), Evoluţia gândirii economice, ed. a III-a, Ed. Academiei Române, Cluj-Napoca: Cartimpex;

10. VÂRŞAN, D., Economie şi politici sociale, available at: (http://www.bibliotecadigitala.ase.ro/biblioteca/carte2.asp?id=374\&idb), last accessed on: 20.01.2016.

\section{Online official documents}

1. Employment and social affairs, at: (https://europa.eu/europeanunion/topics/employment-social-affairs_en), last accessed on: 18.03.2016;

2. Glossary of Statistical Terms, OECD (https://stats.oecd.org/glossary/detail.asp?ID=778), last accessed on 21.05.2017;

3. Report of Romanian National Institute of Statistics on Work force in Romania. Employment and Unemployment, 1993, at: (http://194.117.236.69:7893/Docs/AMIGO_tr3.pdf), last accessed on: 19.05.2016; 
4. Status in employment - History, ILO available at: (http://ilo.org/global/statistics-anddatabases/statistics-overview-and-topics/status-in-employment/history/lang-en/index.htm), last accessed on: 19.05.2016;

5. Resolution concerning the International Classification of Status in Employment (ICSE), adopted by the Fifteenth International Conference of Labour Statisticians, 1993 , available

at: (http://www.ilo.org/public/english/bureau/stat/download/res/icse.pdf), last accessed on: 21.05.2016;

6. Conventions and Recommendations, ILO, available at: (http://ilo.org/global/standards/introduction-to-international-labourstandards/conventions-and-recommendations/lang--en/index.htm), last accessed on: 21.05.2016;

7. EU treaties, at (https://europa.eu/european-union/law/treaties_en);

8. European Parliament, Politica socială și de ocupare a forței de muncă: principii generale, at: (http://www.europarl.europa.eu/atyourservice/ro/displayFtu.html?ftuId=FTU_5.10.1.ht ml), last accessed on: 17.04.2017;

9. Draft of the common report of the Commission and the Council on Employment, 2016, available at: (http://ec.europa.eu/europe2020/pdf/2016/ags2016_draft_joint_employment_report_ro. pdf), last accessed on: 17.02.2017. 